Валерија Б. ЈАНИЋИЈЕВИЋ ${ }^{*}$

Универзитет у Београду

Учитељски факултет
Оригинални научни рад

Примљен: 11. 11. 2016.

Прихваћен: 10. 02. 2017.

\title{
НАСТАВА КЬИЖЕВНОСТИ У ЕСЕЈИМА БОГДАНА ПОПОВИЋА
}

\begin{abstract}
Промишљања Богдана Поповића о теоријским основама наставе књижевности, о којима се до сада мало говорило, основни су предмет овога рада. Она су и данас веома подстицајна, јер долазе од теоретичара који је проучавање и предавање књижевности сматрао јединственим процесом. Богдан Поповић је био свестан да су начелни ставови тек полазиште добре наставе, а да нема добре наставе без доброг читања и разумевања књижевног текста. Зато су његови чувени есеји „О књижевности”, „О васпитању укуса” и „Теорија реда-nо-ред” у подједнакој мери и књижевнонаучни и методички. У времену када се методика конституише као самосвојна дисциплина, Поповићеви текстови поново потврђују став о јединству књижевног знања, наставе и васпитања.

Кључне речи: настава књижевности, методика наставе књижевности, васпитање укуса, теорија реда-по-ред.
\end{abstract}

Педагошки значај Богдана Поповића не само да је велики већ је и одавно примећен у нашој науци о књижевности. О њему као педагогу и методичару између осталих су говорили и писали Милан Кашанин, Слободан Јовановић, Иво Тартаља, Милија Николић. Дајући Поповићев портрет у књизи Судбине u љьуди, Кашанин ће, обухватајући у једној реченици читаву његову делатност, нагласити управо ову Поповићеву страну:

Ни у чему неодређен, Богдан Поповић је и као уредник, и као писац, и као наставник, био потпун. [...] Како се у српској књижевности писало и пише, нама је не само био и остао потребан педагошки оријентисани Богдан Поповић, него ће нам бити потребан увек, и не један (Кашанин 1968: 280).

\footnotetext{
*valerija.janicijevic@uf.bg.ac.rs
} 
Данас је потреба за оваквим Богданом Поповићем још већа. У времену наглашених специјалистичких усмерења и, сходно томе, заснивању методике као засебне науке, „педагошки оријентисан” Богдан Поповић је само други начин именовања за мислиоца који не раздваја своју научну, наставну и етичку делатност, чврсто убеђеног у своју мисију и улогу професије којом се бави. Зато што је Богдан Поповић, уз сву скепсу модерног интелектуалца, дубоко веровао у моћ и деловање књижевности. Има у томе утицаја времена у којем је живео, напора да се религија надомести другим, најпре етичким вредностима, али у истој мери и супротстављања природним наукама, које су у једном периоду и код нас (на пример деловањем Светозара Марковића) имале амбицију да потисну сва друга виђења, све што не може бити од непосредне користи.

Као књижевни теоретичар и естетичар, који је знатан део својих напора уложио да књижевност одбрани од свођења на логику природних наука и на узрочно-последична објашњења Иполита Тена, Богдан Поповић је имао велику веру у моћ књижевности, управо због њене сложене природе. Исказано на другачији начин, његово разликовање природних и друштвених наука у много чему је слично Дилтајевом разликовању објашњењ $а$ и разумевања (насталом крајем 19. века, а које ће постати шире познато неку деценију касније). По много чему је био убеђен да је у време када „просвета потискује и истискује теолошку религију" управо књижевност, између осталих човекових делатности, најпогоднија да је замени. Поготово када је, за разлику од претходних времена, доступна готово свакоме:

Што је пре била својина неколико мандарина, данас постаје општа људска имовина. Тако не само идејама и садржајем својим, но и својим домашајем, она постаје све подобнија да послужи као једно од моћних васпитних средстава наших (Поповић 2001a: 12).

Разматрајући улогу књижевности, Богдан Поповић је увек имао на уму њено, условно речено, уже и шире деловање. Уже се огледало у развоју естетског промишљања књижевности и уметничких дела, а шире у моралном васпитању, које обухвата целог човека: „Но књижевност би очевидно било погрешно сматрати само као средство за васпитање или као студију; далеко од тога. Њена поетска, идеална, осећајна страна, исто су нам тако потребне” (Поповић 2001a: 9).

По свему судећи, поготово ако у први план ставимо одређење „исто су нам тако потребне”, тешко је закључити да Богдан Поповић наглашено раздваја естетичку и васпитну улогу књижевности. Нарочито ако пасус из којег је извод узет, а у којем аутор и естетичку улогу узима у једном специфичном виду, прочитамо до краја. Из истих је разлога појам књижевност код Богдана Поповића унеколико шири него у уобичајеном значењу, бар утолико што је писце моралисте и темељне књиге које књижевност промишљају сматрао књижевним. ${ }^{1}$

\footnotetext{
${ }^{1}$ О односу Богдана Поповића према писцима моралистима видети Јовановић 2001: 340-343.

О односу естетских и практичних циљева видети више у студији Алексић 2014, посебно на страницама 28-35.
} 
Наравно да је Поповић сматрао да само уметнички вредна дела могу да имају васпитну улогу, тако да ово његово нераздвајање, његово исто тако делује сасвим логично. То се, ако је дозвољено приметити, види и у његовом стилу. Аналитичан, одмерен, прецизан, један од утемељивача и најбољих представника београдског стила, он је себи допуштао и песничке узлете који су и сами постајали књижевни, у најужем смислу те речи:

Замислите, господо, у једној горостасној визији, човечанство на нашој земљи, кроз простор и кроз векове, онај огромни мравињак људски, са миријадама својих душа прилепљених за земљу, како гамиже и путује непрекидно, без одмора, у бескрајној и широкој поворци, од постанка до данас - све што су ти људи осећали, мислили, говорили, трпели, покушавали, текли - њихове наде, радости, печали, мудрост, све њихово искуство, дакле оно што је за нас, који смо оно што су и они били, најважније - све се то налази као свод у великој Библији човечанства, у његовој Књижевности (Поповић 2001а: 6).

Књижевност је, читамо у овом наводу, велика колективна меморија, која је премрежила читав земаљски простор и сва времена, чувајући мисли, осећања, надања претходних времена. Називајући је великом Библијом човечанства, он је не само истакао њену непроцењиву вредност него још једном исказао уверење о улози књижевности након опадања утицаја религије. Приступао јој је као недељивој целини, остављајући по страни језичке, националне и временске поделе. Наглашавао је да књижевност (пишући је великим почетним словом) богати наше искуство, снажи емоције, усмерава нас у поступањима, чини да се усавршавамо, сазревамо и постајемо бољи но што јесмо. Да од свих особина човекових посебно гради и снажи осетљивост и моћ симпатије, односно емпатију. Она је, по Богдану Поповићу, врхунска особина - изузетна јер побеђује себичну, саможиву и нагонску природу човекову, стварајући културног, цивилизованог и осећајног човека:

Књижевност уопште васпитава људску осетљивост том својом осећајном страном. Услуга једна, господо, од неоцењиве вредности. Данас, код многих људи, осетљивост, моћ симпатије, нису још довољно развијене; хоћу да кажем да још нису дошле до степена на коме дају сву корист која се од њих може ишчекивати. У свакидашњем животу, који је пун борбе, пун себичности и немилостивог такмичења, човек нема увек прилике да негује увек своје срце, нежна осећања и симпатичне емоције. [...] Међутим, то су особине које на крају треба да превладају; ако ишта, оне има да реше данашње дисонанце у хармоничан акорд, и да донесу са собом културу, цивилизацију [...] Отуда све што помаже да се те особине одгаје и појачају важно је више свега; и књижевност на једном од првих места (Поповић 2001a: 8).

Велико је Поповићево поверење у књижевност. Можда је само из научничких обзира рекао да је „књижевност на једном од првих места”; она је код њега без сумње на првом месту. У овој вери био је садржан још један од његових основних ставова: да само знање без васпитања не може да доведе до стварања човека за каквим је жудео и ка којем је управљао целокупно своје деловање. Можда је најбоље то осетио Слободан Јовановић, аутор једног од најзначајнијих текстова о Богдану Поповићу, када је написао: „Међу нашим студентима на страни, он је једини налазио да није доста 'обогатити се знањем', него треба још примити погледе и навике модерног културног човека, - другим речима, извршити своје преваспитавање” (Јовановић 2001: 
346). По свему судећи, у овој реченици Слободана Јовановића крије се зачетак његовог чувеног текста „Шта је полуинтелектуалац” и чврстог уверења да школа која даје само знање може да ствара рђаве људе: „Школа која се ограничава на давање знања, без упоредног васпитања карактера, није у стању да спречи појаву таквог друштвеног типа као што је полуинтелектуалац" (Јовановић 1991: 572). Зато је Слободан Јовановић често и добро писао о књижевности, сасвим у духу схватања Богдана Поповића. И за једног и за другог научног великана, који су обележили нашу културу крајем 19. и у првој половини 20. века, књижевност је била више од књижевности.

\section{II}

На више места у својим есејима Богдан Поповић говори о образовању као дуготрајном процесу. О времену које је неопходно човеку да се научи да сам посматра и опажа, да „научи самостално и правилно мислити”. Време је потребно и за, по Поповићу, најважнију ствар - за васпитање осећања:

Трудите се да осетите тај осећај, ако тако смем рећи; тако је, уосталом, сасвим тачно казано. Јер осећај је ту; ви сте утисак примили, свој лични утисак; али га нисте свесни, нисте се научили да га издвојите из оног неразговетног стања ваше душе у том тренутку, да га искажете, ви још нисте однеговали у себи ону фину и изванредно важну способност помоћу које човек може да буде свестан онога што се у њему догађа (Поповић 2001а: 15).

Из истих разлога говори о брзоплетости, о времену које је неопходно да се слегну не само утисци већ и знање које човек прима. Због тога је важно нагласити да су за Богдана Поповића васпитање и образовање процес који је једнак развијању и сазревању човекове личности и тек у овом светлу ми у потпуности можемо разумети његов текст „О васпитању укуса”.

Укус је за Богдана Поповића више него укус у свакодневном значењу и више него уобичајено значење у естетикама његовог времена. Васпитање укуса, уз све слободе, треба разумети као опис могућег деловања књижевности на човекову личност и, истовремено, на припрему младог човека да буде отворен за деловање књижевности. Јер, не васпитава се укус, него се гради ситуација да књижевност у естетском и васпитном смислу најпотпуније оствари своје деловање. Синтагму „васпитање укуса” можемо слободно превести и описати као наставничко-ученичко садејство у стварању услова да књижевност испољи своје најбоље моћи.

Поповић укус не посматра у ужем смислу, блиском свиђању, допадању, већ га повезује са самом природом човековог бића, са његовим емоционалним и интелектуалним карактеристикама. То се јасно види када сагледамо девет особина које наводи, а које се крећу од осећања, маште, преко општег и књижевног знања, до дубоког познавања човека и великог животног искуства. Крећу се од онога што је човеку дато до оног што сам мора да стекне, што читамо не само у њиховим описима већ и у редоследу. То је један образовни 
процес који се непрестано креће напред и назад и у који је Богдан Поповић потпуно веровао.

Чак много јасније него у свом знаменитом есеју, Поповић је укус одредио бар на шест места у „Фрагментима из компаративне естетике и теорије лепог". Укус је по њему тако преплет интелекта и финије осетљивости, односно њихова сложеница, а не субјективно и ирационално осећање (Поповић 2001г: 442). Управо супротно од тога. Нема укуса без општег образовања, културе и културног памћења. Зато је апострофирани фрагмент могао и да допуни делом једног од касније наведених: „Укус је већи степен културе, интелекта и осећања" (2001г: 443). Такође, осетио је потребу да још наглашеније изједначи укус са целокупном човековом личношћу. Укус човеков зависи од целине његовог бића, од његових потреба и одговора на те потребе: „Укус неког човека зависи од његовог целог састава и, даље, од његових потреба: укус његов, то су његове потребе. [...] Разуме се, реч је овде о његовим потребама у области естетичнога" (2001г: 461). Поповићево начело могло би да се подведе под став „какав сам ја тако и приступам књижевности и тако је разумем". С тим да то какав сам ја много зависи од нашег претходног доживљаја и читања књижевности.

У тренутку појављивања Поповићево васпитање укуса померило је тежиште са историјских прегледа на доживљај, сензибилитет и културу младих људи, са учења бројних чињеница на разумевање књижевног текста, са памћења података на изграђивање сопственог бића. Колико његових девет особина за васпитање доброг укуса, исто толико је чувен и завршетак овог текста, који је још једна потврда узајамног садејства наставника и ученика и личног улога који свако од њих мора да приложи:

Као што сам рекао: има један пут да се пређе; наставник има да води, али ученик мора на својим ногама прећи цео пут - и саме мостове које му наставник сагради кад је јарак сувише широк за његов, учеников корак (Поповић 2001б: 48).

Таква размишљања о настави књижевности препознао је осам деценија касније Иво Тартаља, заснивајући свој текст „Увођење у књижевност - као проблем, опет нов” на овом и другим ставовима, како га назива витеза естетичког прилажења књижевности. Позивајући се на славног претходника, и сам Тартаља истиче да се стварно увођење у књижевност не обавља путем предавања, већ васпитањем укуса, и не постиже се држањем лекција, већ упућивањем:

Као методичар Богдан Поповић се озбиљно стара да обезбеди самосталност мишљења код ученика, код сваког пријатеља књижевности. У том духу наставник ће ненаметљиво да буди интересовање и да избором лектире усмерава читање; нарочито ће упућивати на добро писана дела и указивати на врлине и мане пишчевог језика и стила (Тартаља 1984: 80).

Између двојице наших најзначајнијих есејиста и професора књижевности у прошломе веку успостављена је пуна сагласност, утолико значајнија што су и један и други сматрали да је служење књижевности неодвојиво од служења настави књижевности. 
Поповићеви есеји „О књижевности”, „О васпитању укуса” и „Теорија реда-по-ред" су у великој мери и методички текстови, што је за последњи од њих аутор отворено и рекао: „У овом огледу, о методи 'реда-по-ред’ биће реч битно о методи наставе, не као о методи научног испитивања" (Поповић 1970: 162). А основно својство Поповићеве методике јесте настава која полази од самог дела и његових конкретних појединости:

Метода „реда-по-ред”, као што јој и име каже, значи методу испитивања, аналисања, критиковања књижевног дела, не у широким, општим потезима, и по његовим најширим, могло би се рећи „апстрактним” особинама, но подробно, из којих се састоје широке особине и последњи ефекти књижевног дела (Поповић 1970: 161).

И знање и однегован укус може дати само она метода наставе која полази од конкретних појединости. Ко буде добро схватио корист ове методе за наставу, знаће у крупним потезима и њене користи за научно испитивање (Исто: 163).

Најпре се у проучавању полази од „ситних, што конкретнијих, техничких појединости, од основних састојака из којих се састоје и на којима се дижу, у много спратова, све шири ефекти, све општије особине уметничких дела, што значи и цела Наука о књижевности и уметности" (Исто: 163). Полазећи од ситнијих, што конкретнијих појединости, проучавалац књижевности, односно наставник се приближава или, тачније речено, не удаљава се од текста, описујући га подробно, а не у општим потезима. Широки потези за Поповића значе оно описивање књижевног текста које сам текст веома мало дотичу и изрицање вредносних судова без поткрепљивања уоченим детаљима текста. То је оно описивање које се одмах уздиже изнад текста, а да у озбиљном смислу од текста није ни пошло. Није немогуће претпоставити да под „широким, општим потезима” Поповић мисли и на свечан, а празан говор о књижевности и исту такву наставу, која може на тренутак и да нас понесе, а после које не остаје ништа. Основни садржај наставе књижевности за Поповића јесте сам текст, као и деловање текста, које је пропорционално његовом разумевању.

Стављајући знак једнакости између конкретних и техничких појединости, Поповић нас враћа на причу о терминима и њихов значај, у овом случају за добру наставу. У књижевној науци термини настају генерализацијом својстава појединачних дела (па и генерализацијом наших искустава о њима). Они јесу апстрактни, али су изведени из конкретних остварења или природе саме књижевности. Зато и јесу щироки и несигурни (како их одређује), али су и сложени и суптилни инструменти описа и разумевања текста, којима се не врши насиље над њим (не подводи се дело под унапред припремљен теоријски калуп). Тек полазећи од конкретних ка све сложенијим слојевима текста и користећи овако изведене књижевне термине, проучавалац књижевности може да се тексту приближи, и да га тумачи, а да не поништи његову природу. По Поповићевом мишљењу, познавање термина омогућава поузданији приступ књижевном делу, али, такође, употребом термина, посебно у настави, не сме да се врши насиље над књижевним текстом. Увођење термина у 
наставу везује се за именовање битних својстава текста и не подразумева њихово учење напамет:

Не треба мислити да је могуће знати књижевне особине, а не знати термине који их бележе. Те две ствари су практично нераздвојне једна од друге. Где појма има, ту има и назива и имена; и обратно, где назива нема, ту се не зна ни за одговарајући појам (2001в: 70).

У поменутом тексту Иво Тартаља није могао да се ослони на боља и потпунија разматрања значаја књижевних термина у настави од ових Поповићевих, изнетих у два есеја.

Приликом увођења у књижевност права материја за наставу у виду предавања било би према Богдану Поповићу објашњавање стручних термина, утврђивање књижевних појмова. Можда овај књижевни естетичар претерује када истиче неопходност познавања књижевних термина и појмова за јасно запажање естетичких особина књижевних дела и уживање у овима, али је свакако тачно да се без поузданог владања терминологијом озбиљан разговор о књижевности не може водити. Савладавање једног техничког термина, међутим, изискује примере којима се живо илуструје оно што се њиме жели именовати (Тартаља 1984: 80).

Богдан Поповић и Иво Тартаља су најдоследније у нас поставили питање места и улоге термина у настави књижевности. Не занемарујући чињеницу да ученици морају да овладају књижевном терминологијом, они су поставили питање мере и улоге термина у настави, усвајајући став да се не стаје на њиховом дефинисању, већ да је циљ познавања термина потпуније разумевање битних својстава књижевног дела. Да је потребно да они буду функционални инструменти књижевне анализе. Наравно, на један начин у основној школи, на други у гимназији, а на трећи на студијама књижевности.

Тек кад се читају методичким очима, у радовима Богдана Поповића се откривају бројни подстицаји колико за наставу књижевности, исто толико и за њено стручно и научно промишљање. Јер, он је своје огледе писао у подједнакој мери и за оне који књижевност читају и за оне који књижевност предају. То су, слободније речено, његови програмски текстови за наставнике, јер је стручним или књижевнотеоријским разлозима за добру интерпретацију додао методичке: једним оком је гледао како ће научити своје студенте разумевању и тумачењу књижевног текста, а другим је сагледавао како ће они учити своје ученике. Знао је, можемо претпоставити, да се културни човек и културна нација не стварају само на семинарима тадашњег Филозофског факултета него у бројним основним и средњим школама у којима ће његови студенти радити.

По томе како је гледао на наставу књижевности, Богдан Поповић јесте један од првих, а свакако је најзначајнији зачетник оног усмерења које се данас све више назива унутарња или иманентна методика у настави књижевности (о иманентној методици видети више у Јанићијевић 2016: 18-22). Улога коју је наменио књижевности - да делује на човекову осећајност, етику и културу, да васпитава укус, развија и богати његову личност, изузетно је велика и њу могу да врше само уметнички вредна дела. Зато настава књижевности треба да сачува пуноћу природе књижевног текста најпре од педагошког редук- 
ционизма. Унапред задате схеме, које своде текст само на фабулу, на један моменат који треба издвојити, или на идеју - иначе честе у настави и данас - тако су супротне начелима Богдана Поповића. Тако осакаћена у наставном процесу књижевност не може да изврши све ове задатке које јој је наменио најпознатији српски књижевни теоретичар и естетичар. То може само настава која прати карактеристичан пут књижевности, односно њено деловање и на ум и на срце. То је његова порука коју савремена методика не сме да превиди. У томе процесу улога наставника је незаменљива. Зато им се тако страсно, доследно и са поверењем обраћао и рачунао на њих.

\section{ЛИТЕРАТУРА}

Алексић 2014: М. Алексић, Богдан Поповић и српска књижевност, Београд: Друштво за српски језик и књижевност Србије.

Бежен 2008: A. Bežen, Metodika - znanost o poučavanju nastavnog predmeta (Epistemologija metodike u odnosu na pedagogiju i edukologiju - s primjerima iz metodike hrvatskoga jezika), Zagreb: Učiteljski fakultet - PROFIL.

Јанићијевић 2016: В. Јанићијевић, Теорија књижевности у разредној настави, Београд: Учитељски факултет.

Јеремић 2001: Д. М. Јеремић, Богдан Поповић у: Б. Поповић, Антологија новије српске лирике (Сабрана дела, књига V), Београд: Завод за уџбенике и наставна средства, 416-461.

Јовановић 1991: С. Јовановић, О културном обрасцу, Из историје и књижевности II (Сабрана дела, књига 12), Београд : БИГЗ, Југославија публик, СК3, 335-364.

Јовановић 2001: С. Јовановић, Богдан Поповић у: Б. Поповић, Антологија новије српске лирике (Сабрана дела, књига V), Београд: Завод за уџбенике и наставна средства, 335-364.

Кашанин 1968: М. Кашанин, Судбине и људи, Београд: Просвета.

Лазаревић 2001: Б. Лазаревић, Богдан Поповић у: Богдан Поповић, Антологија новије српске лирике (Сабрана дела, књига V), Београд: Завод за уџбенике и наставна средства, 365-415.

Поповић 1970: Б. Поповић, Теорија реда-по-ред, Огледи и чланияи из књижевности, Нови Сад: Матица српска: Београд: СКЗ, 145-189.

Поповић 2001а: Б. Поповић, О књижевности, Кюижевна теорија и естетика (Сабрана дела, књига IV), Београд: Завод за уџбенике и наставна средства, 1-20.

Поповић 2001б: Б. Поповић, О васпитању укуса, Кьижевна теорија и естетика (Сабрана дела, књига IV), Београд: Завод за уџбенике и наставна средства, 21-48.

Поповић 2001в: Б. Поповић, Теорија реда-по-ред, Книжевна теорија и естетика (Сабрана дела, књига IV), Београд: Завод за уџбенике и наставна средства, 49-76. 
Поповић 2001г: Б. Поповић, Фрагменти из компаративне естетике и теорије лепог, О уметности и стилу, (Сабрана дела, књига III), Београд: Завод за уџбенике и наставна средства, 431-466.

Николић 2010: М. Николић, Методика наставе српског језика и књижевности, Београд: Завод за уџбенике, 49-76.

Тартаља 1984: I. Tartalja, Uvođenje u književnost - kao problem, opet nov, y: A. Jovanović (prir.), Kako predavati književnost, Beograd: Zavod za udžbenike i nastavna sredstva, 77-89.

Valerija B. Janićijević

\section{LITERATURE TEACHING IN BOGDAN POPOVIĆ ESSAYS}

(Summary)

Bogdan Popović's deliberation about theoreatical basis of literature teaching, that was rarely spoken of, is the basic subject of this work. They are very stimulating even nowadays because they originate from the theoretician who considered studying and teaching as a unique process. Bogdan Popović was aware that basic standpoints are just the beginning of good teaching, adding that there is no good education without satisfactory reading and understanding of the literature text. That is why his famous essays "About literature", "About savour education" and "The theory line-by-line" are in equal circumstances, literary as well as methodical. At this time when teaching methods are being constituted as autonomous discipline, texts by Popović again confirm the attitude about the unity of literature knowledge, teaching and education. 